\title{
Business Cycle and Asset Valuation in the Gaming Industry
}

\author{
Linda Canina, Steven A. Carvell, Qingzhong Ma, Andrey D. Ukhov \\ Cornell University, School of Hotel Administration
}

\begin{abstract}
This study values takeover targets in the gaming industry and finds that privately held takeover targets command lower valuations than publicly traded firms. On average valuation multiples are $46 \%$ lower for private targets relative to public firms. This finding has significant implications for owners of privately held gaming companies who may consider a takeover as an option to maximize shareholder value. The study examines the effect of recessions and expansions on valuation. The discount of private targets relative to public targets is present at all stages of the business cycle. Acquisition targets receive lower valuations in recessions and the relative discount for private gaming firms deepens further in recessions. Jointly, the results suggest that recessions have an important impact on the market for corporate control in the gaming industry.
\end{abstract}

\section{Introduction}

Gaming is a large and economically important industry. Much research focuses on understanding gambler behavior (Hong \& Hochan, 2005; Moss, Ryan, \& Wagoner, 2003; Mowen, Fang, \& Scott, 2009; Soane, Dewberry, \& Narendran, 2010; Thaler \& Johnson, 1990; Vong, 2008). In terms of the impact of gaming externalities on local communities and the economy we see that this industry has unique characteristics (Braunlich, 1996; Chhabra, 2007; Kwan \&McCartney, 2005; Smeral, 1998).

However, few studies consider investment behavior in the gaming industry, which as a regulated industry we may expect to see variances from norms established in the general finance literature. Canina (1996) considers IPO behavior in the gaming sector, but more work is needed in this area. The present paper extends the understanding of the gaming industry's investment behavior by studying the pricing of mergers and acquisition (M\&A) transactions involving gaming companies or gaming assets. The economic significance of $M \& A$ transactions in the gaming industry is substantial, especially considering the 3063 deals announced from the beginning of 1980 through 2009, with a total target 
value of $\$ 916,358$ million and an average target value of $\$ 299$ million. Focusing on one industry rather than all-inclusive study is important to obtain industry-relevant results and managerial implications (Jang \& Young, 2009; Smith, 2006). The findings in this study have implications to corporate executives as well as potential investors interested in the gaming industry.

M\&As are regarded as an important corporate strategy (Collins, Holcomb, Certo, Hitt, \& Lester, 2009; Huyghebaert \& Luypaert, 2010; Kobeissi, Xian, \& Haizhi, 2010; Pablo, 2009). Specifically, acquisitions along with IPO's are methods for investors to monetize their investments through the public and private markets. Acquisitions may bring many benefits, but at the same time they involve substantial risk. Firms can eliminate competitive threats or gain economies of scale or market power through mergers. Firms lacking growth may undertake acquisitions to increase their growth rates. Managers propose that the rationale for an acquisition is an increase in value derived from a variety of sources, such as economies of scale and/or scope from the combined organization and the elimination of poor managerial practice. One of the fundamental reasons why two firms combine their resources is to create value by pursuing these potential synergies between them.

An abundance of empirical research examines the performance of acquirers across all industries and in general fails to find consistent evidence of improvements in value after the acquisition. Lees (2003) points out that the lack of value creation is an unanswered question when it comes to M\&A. Some blame it on paying too much for an M\&A deal or overvaluing the synergy effects while others blame it on the integration process and the fact that those who are responsible for the implementation are often not involved in the previous stages before the deal is made. Researchers also explore how characteristics of the target selection and negotiation processes can lead to overpayment for a target by an acquirer, dooming the transaction from the very start (Hayward \& Hambrick, 1997; Morck, Shleifer, \& Vishny, 1990). Since the value and realization of potential synergies are directly influenced by the price paid for the target firm, the main objective of this paper is to evaluate the pricing of gaming assets. Since overpayment may prevent firms and their investors from realizing acquisition benefits in the gaming industry, correct valuation of the target is a key factor in the M\&A process.

Correct valuation is a fundamental criterion of a successful merger as in all investment decisions (Lee \&We, 2009), as long as the net present value (NPV) of an investment is positive value is enhanced. The NPV is simply the difference between the post merger value of the integrated firm, $V^{c}$, and the sum of the paid acquisition price for the target firm, $\mathrm{P}^{\top}$, and the value of the acquiring firm prior to the merger, $V^{A}$. This difference, the NPV, represents the value of the realized synergy. The total synergy value of a merger may differ from the realized synergy due to differences between the acquisition price 
of the target and the stand alone value of the target, $\mathrm{V}^{\top}$. Total synergy equals the difference between the combined firm value, $V^{C}$, and the sum of each individual firm value, $\left(V^{\top}+V^{A}\right)$, where $V^{\top}$ and $V^{A}$ are the stand alone values of the target and acquirer, respectively. The value of this difference includes the acquirer's valuation of control as well as operating and financial synergies. If the price paid for the target, $\mathrm{P}^{\top}$, is less than the standalone value of the target, VT plus the value of the total synergy, then the NPV will be positive, value is created and the merger is successful. However, if the price exceeds VT plus the value of the total synergy, value is destroyed.

Performance differences occur between acquisitions of private and public targets (Chang, 1998; Officer, 2007). Differences in information availability on private versus public firms influence both the acquirer's choice of target as well as its performance. Lack of information on private firms increases the risk associated with not evaluating properly the assets of the private targets (Reuer \& Ragozzino, 2007). Meanwhile, the lack of information available on private firms provides more opportunities for acquirers to exploit private information and thus gain abnormal returns from buying private targets (Makadok \& Barney, 2001). The market of corporate control for public firms serves as an information processing and asset valuation mechanism for all potential bidders. Hence, in terms of value appropriation, the market for corporate control of public firms is more competitive than that of private firms. In addition, acquirers of private targets can better appropriate the value of their private information thanks to the weaker bargaining power of private targets. Bidder competition and bargaining power of public targets are key elements of value appropriation for target shareholders. Ma, Whidbee, and Zhang (2012) systematically examine these issues for a large sample of listed and unlisted acquisitions.

The impact of economic conditions is important as well since many researchers find that a greater number of merger transactions occur in expansion years when aggregate activity is high (Ma \& Ukhov, 2011; Smeral, 2009). In addition, Shleifer and Vishny (1992) develop a model in which discounted prices are accepted by targets because negative economic shocks force firms into fire sales of assets. Empirical evidence of their model is reported in Kruse (2002).

Acquisition prices of both public and private targets are reported and readily available. However it is not straightforward to measure the price premium or discount relative to the fair value of the assets since the fair value is unknown. This problem is overcome by following a technique developed by Officer (2007). He compares acquisition multiples for private targets to acquisition multiples for portfolios of comparable publicly traded targets. Kaplan and Ruback (1995) find that this technique provides lower average valuation errors in their setting. 
We focus on the influence of acquirer listing status, target listing status, and especially, the economic condition on the absolute and relative pricing (private vs. public targets) of gaming companies and gaming assets. Our investigation starts with a parsimonious Gordon growth valuation model to explore how target listing status and economic shocks influence valuation. The predictions are supported by the data. Specifically, we find the following results. First, private targets receive lower valuation multiples than publicly traded targets within the gaming sector. More specifically, when all acquirer types (public and private acquirers) are considered jointly, we find that private gaming firms are sold at lower valuation multiples than public firms; on average, valuation multiples are $46 \%$ lower for private acquisition targets than for public targets; and, private firms receive lower multiples relative to public firms, in acquisitions by both public and private acquirers.

We then investigate the acquisition discount further. The study finds that the business cycle recessionary and non-recessionary periods - plays an important role in the valuation of takeover targets. Our results show that multiples paid during recessions are lower than valuation multiples paid during non-recessionary periods; the discount of private targets relative to public targets is present both in expansions and in recessions; the discount for private firms deepens in recessions; and jointly, the results suggest that recessions have an important impact on the market for corporate control within the gaming sector. These results are especially important given the significant number of private acquisition transactions that occurred during our sample period.

The remainder of the paper is organized as follows. We start with a parsimonious valuation model to explore how target listing status and shocks to economic conditions influence valuations in M\&A transactions. We then report the empirical findings. After a brief discussion of the related literature we discuss the managerial implications and conclude.

\section{Conceptual Approach}

The Gordon growth model is the framework followed in this study. The effect of recessions on other valuation multiples can be analyzed in a similar manner. Without loss of generality, we focus on $\mathrm{P} / \mathrm{E}$ ratio to illustrate the conceptual framework. According to this valuation framework, the value of the business, $P$, is given by,

(1)

$$
P=\frac{E}{r-g},
$$


where $E$ is the value of earnings from the business, $r$ is the discount rate that reflects the risk of the future earnings stream, and $\mathrm{g}$ is the expected growth rate for earnings. Eq. (1) can be re-written in terms of Price-to- Earnings ratio, or $\mathrm{P} / \mathrm{E}$ ratio, $\mathrm{P} / \mathrm{E}=1 / \mathrm{r}-\mathrm{g}$.

The ratio reflects both the risk of the business (the discount rate $r$ ) and the growth prospects of the business, the growth rate g. All else equal, firms with lower growth prospects (lower g) will have a lower $\mathrm{P} / \mathrm{E}$ ratio.

Within this valuation framework, economic shocks, such as recessions, can impact value $\mathrm{P}$ by affecting the discount rate $r$ and the expected growth rate, g. Consider these effects. In recessions, growth prospects of firms are re-evaluated and are adjusted downward. A lower growth rate, $g$ results in a lower valuation multiple, $\mathrm{P} / \mathrm{E}$. Stated formally, $\mathrm{P} / \mathrm{E}$ is an increasing function in $\mathrm{g}$,

$$
\frac{\frac{\partial P}{E}}{\partial g}=\frac{\partial}{\partial g}\left[\frac{1}{r-g}\right]=\frac{1}{(r-g)^{2}}=\left(\frac{P}{E}\right)>0 .
$$

Another source of the effect can be due to changes in the discount rate. There are several reasons why worsening economic conditions can lead to an increase in the discount rate. As appetite to take risks decreases in recessions, or investors are more risk-averse, the discount rate increases. In addition, the cost of capital may rise in recessions due to worsening liquidity conditions (Goddard, Tavakoli, \& Wilson, 2009; Goyenko, Subrahmanyam, \& Ukhov, 2011; Goyenko \& Ukhov, 2009). A higher discount rate results in a lower valuation multiple, $P / E$.

$$
\frac{\frac{\partial P}{E}}{\partial r}=\frac{\partial}{\partial r}\left[\frac{1}{r-g}\right]=\frac{-1}{(r-g)^{2}}=\left(\frac{P}{E}\right)^{2}<0 .
$$

Implication 1: Valuation is Lower in Recessions

We can also use this framework to evaluate the effect of recessions on relative valuation of private targets vs. public targets. Define excess valuation multiple, Excess $P / E$, as the percentage difference between $\mathrm{P} / \mathrm{E}$ ratio of a private firm and a corresponding (similar) public target,

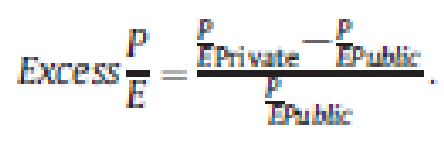

The Excess $\mathrm{P} / \mathrm{E}$ ratio can change if changing economic conditions bring about a change in $\mathrm{P} / \mathrm{E}$ ratios of public and private firms. For this discussion we maintain the assumption that P/E ratio of 
private firms is lower than the $\mathrm{P} / \mathrm{E}$ ratio for similar public firms, and therefore the Excess $\mathrm{P} / \mathrm{E}$ ratio is negative. In the empirical section that follows, we show that private firms are sold at a discount to public firms, and the excess ratio is negative in the data.

The liquidity constraint of the target is a major source of differences in valuation of private and public targets (Officer, 2007). Consider the case when private and public firms have the same (industryspecific) growth rates, $g$, but different discount rates, $r_{\text {Private }}$ and $r_{\text {Public }}$. The $P / E$ ratio for public firms being higher than the $\mathrm{P} / \mathrm{E}$ ratio for private firms is consistent with the discount rate for public firms being lower than the discount rate for private firms, $r_{\text {Private }}>r_{\text {Public }}$. The discount rate is decomposed into a rate of return common to the private and public firms that captures industry characteristics, $r$, and the component that captures the liquidity premium, $\mathrm{LIQ}$, and the exposure of private and public firms to the liquidity premium, liquidity betas, $\beta_{\text {private }} \beta_{\text {public }}$. The discount rates are then: $r_{\text {private }}=r+\beta_{\text {private }} \cdot \mathrm{LIQ}$, and $r_{\text {public }}=r+\beta_{\text {public }} \cdot$ LIQ.

There are several reasons to assume that private firms, especially in the gaming industry, are more vulnerable to economic shocks due to their liquidity constraints, with $\beta_{\text {private }}>\beta_{\text {public. }}$ Public firms tend to be larger and have better access to capital market. The choice for private firms is more limited and a shock can have a more severe impact on private firms due to their lack of liquidity relative to public firms. Under these assumptions and the assumption that $(r-g)>0$, which is reasonable and common to assume the Gordon growth model, the Excess P/E ratio is a decreasing function in the liquidity premium, LIQ,

$$
\frac{\partial}{\partial L I Q} \text { Excess } P / E=\frac{\left(\beta_{\text {public }}-\beta_{\text {private }}\right) \cdot(r-g)}{\left(r+\beta_{\text {privest }} \cdot L Q-g\right)^{2}}<0 .
$$

In a recession, the liquidity premium may increase due to worsening liquidity conditions (Goyenko \& Ukhov, 2009; Goyenko et al., 2011). In this setting, a positive shock to the liquidity premium LIQ will lead to a lower Excess P/E ratio.

\section{Implication 2}

Excess $\mathrm{P} / \mathrm{E}$ ratio is lower during recessions. If private gaming firms sell at a discount to public targets, Excess $\mathrm{P} / \mathrm{E}$ ratio is negative, and a decrease in Excess $\mathrm{P} / \mathrm{E}$ implies that private firms may be discounted more deeply in recessions.

We use $\mathrm{P} / \mathrm{E}$ ratio to analyze how changes in economic conditions affect valuation. We now discuss our empirical results. 


\section{Data}

The data source is Securities Data Corporation (SDC) Platinum database. The data cover all M\&A transactions in the gaming industry for a thirty-year period from 1980 to 2009 . When imposing the constraint that Deal Value to Sales is available, our data start from the second quarter of 1981, as shown in Fig. 1. The long period of study allows us to capture a variety of economic conditions - recessions and non-recessionary periods. We use recession dates defined by the NBER (The National Bureau of Economic Research). We refer to the times of NBER recessions as recessionary times. Times that do not correspond to recessions are expansionary times. Specifically, we define the following months as recessionary times: January 1980 to July 1980; July 1981 to November 1982; July 1990 to March 1991; March 2001 to November 2001, and December 2007 to June 2009.

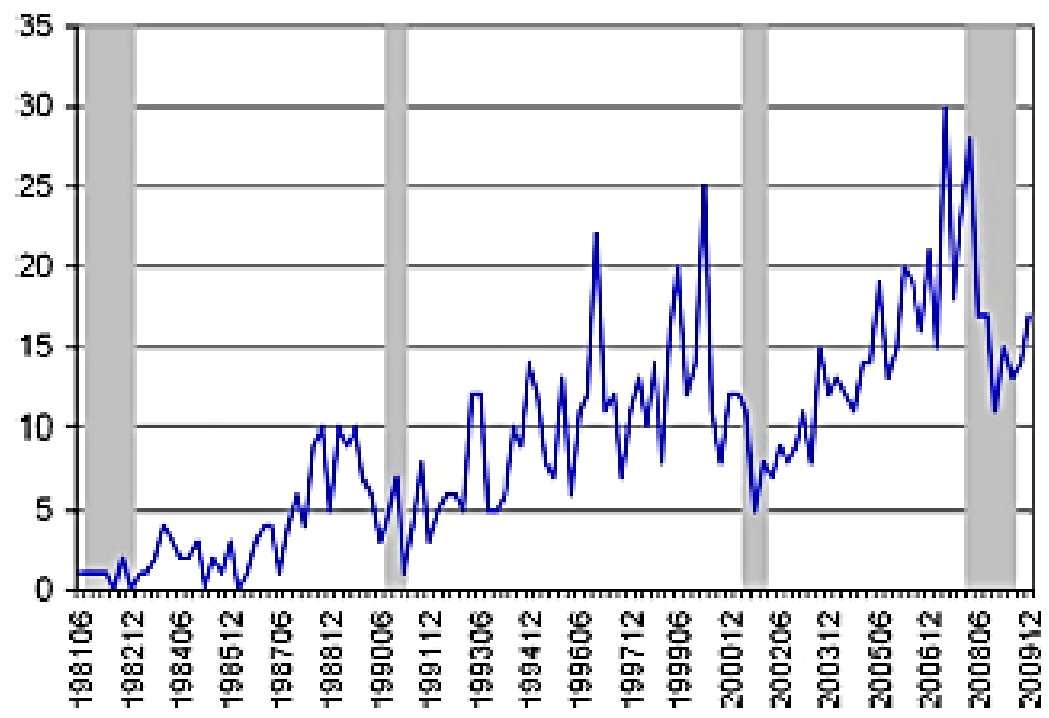

Fig. 1. The quarterly number of transactions in thp gaming industry. Shaded vertical bars indicate NBER recessions. A quarter is shaded as a recession if at least two months of the quarter were in NBER recessions.

In forming the sample of M\&A transactions, we apply the following commonly employed filters.

Either the acquirer or the target has the following key words in its business description: Casino, bingo, betting, race, racing, gambling, gamble, gaming, lottery, and lotteries. The target is either a publicly traded company, a subsidiary, or a privately-held company. Buybacks, exchange offers, and recapitalizations are excluded. The deal size is at least $\$ 1$ million.

The resulting sample consists of 3063 completed M\&A. The sample size varies across analyses due to data availability. We report the number of observations for each test in the corresponding table. In the gaming industry, M\&A activity has been increasing over time. The number of transactions per 
year increased from 247 to 1772 during the 1980 s and 2000s, respectively. Private target acquisitions are also important in the gaming industry. They represent $67 \%$ of the sample.

\section{Results}

Mergers and Acquisitions in the Gaming Industry

Fig. 1 shows the distribution of transactions. The figure plots the number of transactions in each quarter from 1980 through the end of 2009. Shaded vertical bars indicate NBER recessions. The figure suggests that deal volume drops during and around recessions, which temporarily reverses the general increasing trend. In addition to an impact on deal volume, recessions can also have an effect on the valuation of the transactions.

\section{Relative Valuation of Private and Public Targets}

Table 1 shows valuation multiples for target firms, by target and acquirer public status. To deal with outliers, we winsorize the sample at the 1 and 99 percentiles. The main conclusions are also robust to winsorizing at the 5 and 95 percentiles and to no winsorizing at all. We first focus on the comparison of valuation of private and public targets for all acquirer types. Private firms are sold at lower valuation multiples than public firms. For example, the median Deal Value to Sales ratio is 1.70 for public targets, but 1.20 for private targets (the difference between the two values is significant, $Z=-4.04$ ). The evidence suggests that private gaming companies are valued at lower multiples relative to publicly traded firms.

To further investigate the relative valuation, we separate the sample by the type of acquiring firm(public and private acquirers). First, we observe that private gaming firms receive lower valuation multiples in acquisitions by both private and public acquirers. As Table 2 shows, these results hold for both public acquirers and private acquirers. In acquisitions by public acquirers, the median of the Deal Value to Sales ratio is 1.72 for public targets, but 1.27 for private companies (the difference between the two values is significant, with $Z$ of -2.82 ). In acquisitions by private acquirers, the median of the Deal Value to Sales ratio is 1.68 for public targets, but 1.03 for private companies (Z-value for the difference is -3.40$)$.

Another metric, the price to EPS ratio, supports these findings. The empirical evidence that appears in Table 2 shows that the median values of the ratios are lower for private targets than public targets. Both the mean and median values of the ratios are never significantly greater for the private targets than the public targets. In fact for two of the four ratios they are significantly lower. 


\section{Acquisition discounts}

The evidence that valuations of privately held firms are lower in acquisitions is also seen when we examine excess multiples (Table 2). In addition to the evidence on absolute valuation levels discussed above, we also compare relative valuation of private to a matched portfolio of public targets. We follow the technique proposed by Officer (2007). The comparable firm is implemented in the following way. For each unlisted target we form portfolios of comparable acquisitions of publicly traded targets, where comparable acquisitions are those with similar deal value and time period. More specifically, for each private target we find its matching publicly traded targets. We match on transaction size and on the time period (the matched public targets come from takeovers within a threeyear window centered on the announcement date of the takeover of the private firm). The average multiple of the matching public targets is used as the benchmark. We then compute excess valuation multiple as a percent difference between the valuation multiple for the private firm and the average valuation multiple for the portfolio of matched public targets,

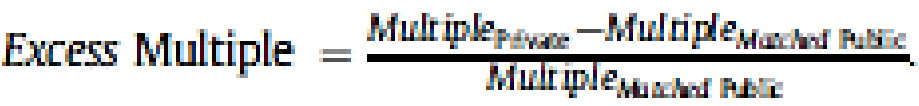

Table 2 presents the percent difference between acquisition multiples for an unlisted firm and for a portfolio of matched publicly traded targets. We refer to them as acquisition discounts of private targets relative to public targets. Negative values indicate that a private company sold at a discount to a matched portfolio. Following Officer (2007), we discard observations with excess multiples greater than $100 \%$.

Private gaming firms sell at a significant discount relative to the publicly traded firms. The average of the four 'excess' multiples studied is -0.46 indicating, that private gaming firms sell at lower multiples than public companies. The discounts are significant for acquisitions engaged in by public acquirers (the discount is -0.4 ), and for acquisitions by private acquirers (the discount is -0.52 ).

The evidence of valuation discount emerges in individual ratios as well. For example, the Deal Value to Sales ratio is $49 \%$ lower in acquisitions of private firms. Almost every multiple displayed in Table 2 produces significantly negative estimates of the average and median acquisition discount. The only exception is for price to book value of equity multiple, where the discount is insignificant. That aside, the majority of the evidence in Table 2 suggests that private gaming targets are acquired at significantly lower multiples on average (and at the median) than are comparable publicly traded firms. 
Table 1

Raw valuation mul tip les by acquirer public status and target publicstatur.

\begin{tabular}{|c|c|c|c|c|}
\hline Sumple & All targts & Public turgets & Privaz targets & Privre-public \\
\hline \multicolumn{5}{|c|}{ Panel A: doal rehuz bales } \\
\hline Whole & $\begin{array}{l}7.43^{* *} \\
(1.58) \\
1064\end{array}$ & $\begin{array}{l}7.58^{* * *} \\
(1.20)^{* *} \\
(717)\end{array}$ & $\begin{array}{l}7.12^{* * *} \\
(1.20)^{-*} \\
1347\end{array}$ & $\begin{array}{l}-0.24 \\
(-404)^{*-}\end{array}$ \\
\hline Acr is public & $\begin{array}{l}828^{\circ} . \\
(1.56) \\
{[648]}\end{array}$ & $\begin{array}{l}860^{2 *}+ \\
(1.72)^{*-} \\
(376)\end{array}$ & $\begin{array}{l}7.83^{2}+. \\
(1.27) \\
(272]\end{array}$ & $\frac{-0.30}{(-282)^{*-}}$ \\
\hline Acrg is privite & $\begin{array}{l}610^{\circ *} \\
(1.59)^{-*} \\
{[416]}\end{array}$ & $\begin{array}{l}645^{2 *} \\
(1 \mathrm{RS})^{* *} \\
{[341]}\end{array}$ & $\begin{array}{l}4.53 \\
(1.03)=- \\
75\end{array}$ & $\begin{array}{l}-0.57 \\
(-340)^{*-}\end{array}$ \\
\hline $\begin{array}{l}\text { T(Acq: Prv-Pub) } \\
\text { Z(Acq: Prv-Pub) }\end{array}$ & $\begin{array}{l}-128 \\
(009)\end{array}$ & $\begin{array}{l}-1.04 \\
(0.03)\end{array}$ & $\begin{array}{l}-0.91 \\
(-1.54)\end{array}$ & \\
\hline \multicolumn{5}{|c|}{ Panel B: deal vahue,EBIIDA } \\
\hline Whole & $\begin{array}{l}21.58^{* *} \\
(956)=. \\
{[612]}\end{array}$ & $\begin{array}{l}2123 \cdots \\
(985)^{* \cdots} \\
{[497]}\end{array}$ & $\begin{array}{l}23.11^{* \cdots} \\
(855) \cdots \\
{[115]}\end{array}$ & $\begin{array}{l}a_{33} \\
\left(-\omega_{7} 7\right)\end{array}$ \\
\hline Acr is public & $\begin{array}{l}23.47^{* \cdots} \\
(10.33)^{* \cdots} \\
{[345]}\end{array}$ & $\begin{array}{l}22.10^{-*} \\
(1053)^{* \ldots *} \\
{[262]}\end{array}$ & $\begin{array}{l}27.78 \\
(968)=* \\
1831\end{array}$ & $\begin{array}{l}a>2 \\
(-0,47)\end{array}$ \\
\hline Ac口 is privite & $\begin{array}{l}19.15^{* . *} \\
(8.45) \\
{[267]}\end{array}$ & $\begin{array}{l}2025=\cdot \\
(861)^{20} \\
{[235]}\end{array}$ & $\begin{array}{l}11.01^{* * *} \\
(7.68) \\
{[32]}\end{array}$ & $\begin{array}{l}-213^{* *} \\
(-124)\end{array}$ \\
\hline $\begin{array}{l}\text { T(Acq: Prv-Pub) } \\
\text { Z(Acq: Prv-Pub) }\end{array}$ & $\begin{array}{l}-092 \\
(-231)^{*}\end{array}$ & $\begin{array}{l}-0.35 \\
(-1.93)^{*}\end{array}$ & $\begin{array}{l}-2.32^{-} \\
(-1.49)\end{array}$ & \\
\hline \multicolumn{5}{|l|}{ Penel C: prics'EPS } \\
\hline Whole & $\begin{array}{l}51.95^{* * *} \\
(24.15)^{* *} \\
{[610]}\end{array}$ & $\begin{array}{l}5227 \cdots \\
(2570) \cdots \\
{[466]}\end{array}$ & $\begin{array}{l}5093^{* * *} \\
(1550)^{\prime \prime} \\
{[144]}\end{array}$ & $\frac{-a 13}{(-388)^{*}}$ \\
\hline Acr is public & $\begin{array}{l}5205 * * * \\
(2300)^{* *} \\
{[353]}\end{array}$ & $\begin{array}{l}5105 \cdots \\
(2420)^{* * *} \\
{[252]}\end{array}$ & $\begin{array}{l}5431^{* \cdots *} \\
(18.40)^{-0} \\
(1111\end{array}$ & $\begin{array}{l}0.28 \\
(-2.16)^{* *}\end{array}$ \\
\hline Acq is privise & $\begin{array}{l}51.82 * * \\
(25 \notin 0)^{* *} \\
{[247]}\end{array}$ & $\begin{array}{l}53.71 \cdots \\
(2730)^{* \cdots} \\
{[214]}\end{array}$ & $\begin{array}{l}3955^{\circ} \\
(1350)^{-*} \\
{[33]}\end{array}$ & $\begin{array}{l}-064 \\
(-394)^{*-}\end{array}$ \\
\hline $\begin{array}{l}\text { T(Acq: Prv-Pub) } \\
\text { Z(Acq: Prv-Pub) }\end{array}$ & $\begin{array}{l}-0.3 \\
(034)\end{array}$ & $\begin{array}{l}031 \\
(0.20)\end{array}$ & $\begin{array}{l}-0.63 \\
(-1.87)^{\circ}\end{array}$ & \\
\hline \multicolumn{5}{|c|}{ Punel D: price/book vehe equity } \\
\hline Whole & $\begin{array}{l}424^{4}+ \\
(242) \\
{[503]}\end{array}$ & $\begin{array}{l}429^{* \cdots} \\
(2.44)^{*-\cdots} \\
{[490]}\end{array}$ & $\begin{array}{l}2.35^{* \cdots} \\
(1.69) \\
{[13]}\end{array}$ & $\begin{array}{l}-339^{* * *} \\
(-124)\end{array}$ \\
\hline Acr is public & $\begin{array}{l}467^{2 *}= \\
(254) \\
{[278]}\end{array}$ & $\begin{array}{l}477^{40 .} \\
(2 \mathrm{fa3})^{*-} \\
{[267]}\end{array}$ & $\begin{array}{l}222=\ldots \\
(1.09) \\
{[11]}\end{array}$ & $\begin{array}{l}-3.74^{* * *} \\
(-165)^{*}\end{array}$ \\
\hline Acq is privite & $\begin{array}{l}3.72 \\
(231)= \\
12251\end{array}$ & $\begin{array}{l}3.72 \\
(2.31)^{* *} \\
{[223]}\end{array}$ & $\begin{array}{l}305 \\
(305) \\
{[2]}\end{array}$ & $\begin{array}{l}-0.40 \\
(0.23)\end{array}$ \\
\hline $\begin{array}{l}\text { T(Acq: Prv-Pub) } \\
\text { Z(Acq: Prv-Pub) }\end{array}$ & $\frac{-205^{* *}}{(-1.82)^{*}}$ & $\frac{-220^{* *}}{(-203)^{-}}$ & $\begin{array}{l}a-1 \\
(030)\end{array}$ & \\
\hline
\end{tabular}

Not: We report the Mean, Median, in parenthes, and the Number of observarion, in bradkets in exh alzgory. The last column report the test statisics terting differences betweer public and privat argets and the last two rows of exh parel repart the test statistics testing betwen public and privat xquirers. The zst statistics are based on two-sampl tstatistio or Wil cowon rmksum tents Thesymbols . . . indicat statis. tial significance at $1 \%, 5 \%$, and $10 \%$ levek, respectively. 
Table 2

Acquisibon discourts, excess vluxion multiples by acquirer public statuk.

\begin{tabular}{|c|c|c|c|}
\hline All & Acq-public & Acq-privat & Acq $\left(P_{R}-p u b\right)$ \\
\hline $\begin{array}{l}\text { Penel A: ara } \\
-046 \\
(-061) \\
{[303]}\end{array}$ & $\begin{array}{l}\text { ge of the four } \\
-0.45 \\
(-0.59) \\
{[234}\end{array}$ & $\begin{array}{l}-0.52^{*}- \\
(-0.65)^{-1} \\
{[6]}\end{array}$ & $\begin{array}{l}-1.06 \\
(-0.36)\end{array}$ \\
\hline $\begin{array}{l}\text { Penel B: oxa } \\
-0.49 \\
(-0,0 s) \\
{[2 \pi 9]}\end{array}$ & $\begin{array}{l}\text { ahy bales } \\
-0.48 * \\
(-0.67) \\
{[214]}\end{array}$ & $\begin{array}{l}-a 5 s^{*-1} \\
(-a 68)^{-0} \\
{[65]}\end{array}$ & $\begin{array}{l}-078 \\
(-0.16)\end{array}$ \\
\hline $\begin{array}{l}\text { Panel C: axa } \\
-0.40 * \\
(-0.58) \\
{[87]}\end{array}$ & $\begin{array}{l}\text { ahe (EBIDAA } \\
-042^{* *} \\
(-0.56) \\
{[60]}\end{array}$ & $\begin{array}{l}-a 36 \cdot 0 \\
(-a 65)^{*} \\
{[27]}\end{array}$ & $\begin{array}{l}0.38 \\
(0.16)\end{array}$ \\
\hline $\begin{array}{l}\text { Penel D: oxas } \\
-0.48 \\
(-0.60) \\
{[102]}\end{array}$ & $\begin{array}{l}\text { EPS } \\
-0.43 * . \\
(-0.59) \\
{[74]}\end{array}$ & $\begin{array}{l}-0.61 * \\
(-0.61)^{*} \\
{[28]}\end{array}$ & $\begin{array}{l}-260^{* *} \\
(-1.14)\end{array}$ \\
\hline $\begin{array}{l}\text { Panel E: exce } \\
-035 \\
(-0.50) \\
{[10]}\end{array}$ & $\begin{array}{l}\text { book rehe oqu } \\
-034 \\
(-0.50) \\
{[8]}\end{array}$ & $\begin{array}{l}-a 39 \\
(-a 39) \\
{[2]}\end{array}$ & $\begin{array}{l}-a 15 \\
\left(a_{13}\right)\end{array}$ \\
\hline
\end{tabular}

Not: We report the mem, medim (in prenthes), and the number of obsevations (in bradkets) for each cregory. The test statistic (last column) are based on two-s mple t-stristics or Wilcowon rank sum tests. Thesymbols "..". " indicat sta. tistical significance at $1 \%, 5 \%$, and 10 r levek, respectively

The Effect of the Business Cycle

We now examine the impact of business cycle on both the absolute valuation multiples and the relative valuation multiples between private and public targets. In Table 3 we compare multiples paid for public and private gaming targets during recessions and in non-recessionary periods. The results presented in the table suggest that the multiples paid in recessions are lower than the multiples during non-recessionary periods. The Deal Value to Sales ratio, for example, equals 7.43 on average, across all target types. The number, however, is substantially lower in recessions and equals 4.85 , compared to 7.85 in non-recessionary times.

For public targets, recessions mostly affect the price to book value of equity. As Table 3 shows, for public targets this multiple equals 4.29 on average, but equals 3.98 in recessions vs. 4.34 in nonrecessionary times (a nearly 10\% decline). For private firms, the impact of recessions on valuation multiples can be seen in several multiples. The ratio of Deal Value to Sales drops from 7.77 in non- 
recessions to 2.62 in recessions. The ratio of Price to EPS drops from the average of 54.16 in non-

recessions to 26.78 in recessions (the medians are 15.6 and 14.3, respectively). In sum, there is evidence that valuation is lower in recessions.

\begin{tabular}{|c|c|c|c|c|}
\hline Sumple & All targets & Public targets & Privite targets & Privat-public \\
\hline \multicolumn{5}{|c|}{ Pencl A: ded velue/sules } \\
\hline WholejLV & $\begin{array}{l}7.43^{m+6} \\
(1.58)^{*+6} \\
{[1064]}\end{array}$ & $\begin{array}{l}7.58^{6+4} \\
(1.70)^{*+*} \\
{[717]}\end{array}$ & $\begin{array}{l}7.12^{-6+} \\
(1.20)^{*+4} \\
{[3.47]}\end{array}$ & $\frac{-0.24}{(-404)^{* *}}$ \\
\hline Nan recession (NR) & $\begin{array}{l}785^{2 .} . \\
(1.60)^{* 6 *} \\
{[913]}\end{array}$ & $\begin{array}{l}7.90^{2+4} \\
(1.74)^{*+\infty} \\
{[610]}\end{array}$ & $\begin{array}{l}7.77^{6+} \\
(1.25)^{*+4} \\
{[303]}\end{array}$ & $\begin{array}{l}-0.06 \\
(-384)^{* \cdot}\end{array}$ \\
\hline Recession (R) & $\begin{array}{l}485^{2+*} \\
(1.27)^{*+6} \\
{[151]}\end{array}$ & $\begin{array}{l}5.7^{2+4} \\
(1.43)^{*-6} \\
{[107]}\end{array}$ & $\begin{array}{l}2.62^{2+*} \\
(099)^{*+*} \\
{[44]}\end{array}$ & $\begin{array}{l}-1.69^{*} \\
(-1.43)\end{array}$ \\
\hline $\mathrm{T}(\mathrm{R}-\mathrm{NR})$ & $-1.86^{\circ}$ & -1.00 & $-263^{*+*}$ & \\
\hline$Z(R-N R)$ & $(-1 A 7)$ & $(-1.17)$ & $(-1.10)$ & \\
\hline \multicolumn{5}{|c|}{ Panel B: deal vahue (EBIDA } \\
\hline Whole & $\begin{array}{l}21.58^{* 0 *} \\
(9.56)^{*+*} \\
{[612]}\end{array}$ & $\begin{array}{l}2123^{*+*} \\
(985)^{*-*} \\
{[497]}\end{array}$ & $\begin{array}{l}2311^{*+\infty} \\
(855)^{*+*} \\
{[115]}\end{array}$ & $\begin{array}{l}a 33 \\
(-0.77)\end{array}$ \\
\hline Nan recession (NR) & $\begin{array}{l}21.19^{* 0} \\
(9.48)^{*+*} \\
{[534]}\end{array}$ & $\begin{array}{l}20.40^{*+*} \\
(960)^{*-*} \\
{[433]}\end{array}$ & $\begin{array}{l}2457^{*+6} \\
(8.45)^{*+*} \\
{[101]}\end{array}$ & $\begin{array}{l}0.66 \\
(-046)\end{array}$ \\
\hline Recession $(R)$ & $\begin{array}{l}2429^{* \infty} \\
(11.11)^{*+*} \\
{[78]}\end{array}$ & $\begin{array}{l}2684^{-6} \\
(11.48)^{*+*} \\
{[64]}\end{array}$ & $\begin{array}{l}1261^{* \cdots} \\
(9.19)^{*+*} \\
{[14]}\end{array}$ & $\begin{array}{l}-1.61 \\
(-0.98)\end{array}$ \\
\hline $\mathrm{T}(\mathrm{R}-\mathrm{NR})$ & 0.43 & a.s & $-1.80^{\circ}$ & \\
\hline$Z(R-N R)$ & $(1.29)$ & $(153)$ & $(-0.17)$ & \\
\hline \multicolumn{5}{|l|}{ Panel C: pricr/EPS } \\
\hline Whole & $\begin{array}{l}51.95^{* *} \\
(24.15)^{*+*} \\
{[610]}\end{array}$ & $\begin{array}{l}5227^{-6 *} \\
(2570)^{*+*} \\
{[466]}\end{array}$ & $\begin{array}{l}50.93^{*+*} \\
(15.50)^{*+*} \\
{[144]}\end{array}$ & $\begin{array}{l}-0.13 \\
(-388)^{* *}\end{array}$ \\
\hline Nan recession (NR) & $\begin{array}{l}5246^{* 6} \\
(2440)^{*+*} \\
{[529]}\end{array}$ & $\begin{array}{l}5193^{-6} \\
(25.80)^{*+*} \\
{[402]}\end{array}$ & $\begin{array}{l}5416^{*+6} \\
(1560)^{*+*} \\
{[127]}\end{array}$ & $\begin{array}{l}0.20 \\
(-3.53)^{* *}\end{array}$ \\
\hline Recession (R) & $\begin{array}{l}48.60^{*-\infty} \\
(21.40)^{*+*} \\
{[81]}\end{array}$ & $\begin{array}{l}54.40^{-*} \\
(24.40)^{*+*} \\
{[64]}\end{array}$ & $\begin{array}{l}26.78^{*+*} \\
(1430)^{*+*} \\
{[17]}\end{array}$ & $\begin{array}{l}-1.94^{*} \\
(-1.72)^{*}\end{array}$ \\
\hline $\begin{array}{l}\mathrm{T}(\mathrm{R}-\mathrm{NR}) \\
\mathrm{Z}(\mathrm{R}-\mathrm{NR})\end{array}$ & $\begin{array}{l}-0.36 \\
(-0.36)\end{array}$ & $\begin{array}{l}0.19 \\
(-0.56)\end{array}$ & $\begin{array}{l}-218^{* 0} \\
(-0.68)\end{array}$ & \\
\hline \multicolumn{5}{|c|}{ Penel D: price/book velue equity } \\
\hline Whole & $\begin{array}{l}424^{6+} \\
(242)^{*+*} \\
{[503]}\end{array}$ & $\begin{array}{l}429^{6+6} \\
(244)^{*-6} \\
{[490]}\end{array}$ & $\begin{array}{l}2.35^{* 0+} \\
(1.69)^{*+6} \\
{[13]}\end{array}$ & $\begin{array}{l}-3.39^{-4} \\
(-124)\end{array}$ \\
\hline Non recession (NR) & $\begin{array}{l}430^{26+} \\
(2.50)^{*+*} \\
{[433]}\end{array}$ & $\begin{array}{l}434^{2+6} \\
(254)^{*-10} \\
{[422]}\end{array}$ & $\begin{array}{l}2.50^{\infty+4} \\
(231)^{*+*} \\
{[11]}\end{array}$ & $\begin{array}{l}-280^{\circ} \\
(-103)\end{array}$ \\
\hline Recession (R) & $\begin{array}{l}391^{2 *} \\
(200)^{*+*} \\
{[70]}\end{array}$ & $\begin{array}{l}398^{26+} \\
(203)^{*-6} \\
{[68]}\end{array}$ & $\begin{array}{l}1.50^{\circ} \\
(1.50) \\
{[2]}\end{array}$ & $\begin{array}{l}-3.38^{20} \\
(-0.72)\end{array}$ \\
\hline $\begin{array}{l}\mathrm{T}(\mathrm{R}-\mathrm{NR}) \\
\mathrm{Z}(\mathrm{R}-\mathrm{NR})\end{array}$ & $\begin{array}{l}-0.52 \\
(-2.10)^{*+}\end{array}$ & $\begin{array}{l}-0.47 \\
(-200)\end{array}$ & $\begin{array}{l}-1.57 \\
(-0.69)\end{array}$ & \\
\hline
\end{tabular}

Not: We report the mean, median (in parenthese) and the number of observations (in bradets) for exh cazgory. Recession is defined according to NHER. The last column reports the test staristics testing differences between listed and unlisted targets and the last two rows of each pund report the test satisbics testing differences between non-recessions and recessions. The test strivics are based on two-smple ts tabstics or Wilowon rank sum tests. The symbols **, "*." indicat stristical significance at $1 \%$ 5\%, and $10 \%$ leveds, respectively. 
Table 3 also reveals some evidence that the differences in valuation multiples of private and public firms exist both during recessions and in non-recessionary times. Consider for example Price to EPS ratio. As the Z-value in the last column indicates, the difference in this ratio for public targets and private firms is significant in the sample, both in non-recessionary and in recessionary periods. Overall, the finding that private firms receive lower valuation multiples than public firms does not appear to be driven by a particular stage of the business cycle.

The evidence of discounts in recessions is also seen when we examine excess multiples. Table 4 presents the percent difference between acquisition multiples for an unlisted firm and for matched portfolio of publicly traded targets. We refer to them as acquisition discounts of private targets relative to public targets. The average of four excess multiples is -0.46 (indicating, as stated above that private firms sell at $46 \%$ lower multiples than public companies). The discount for private firms deepens in recessions. The average of four excess multiples is -0.65 in recessions (a $65 \%$ discount), relative to -0.44 (a 44\% discount) in non-recessionary times, and this difference is strongly statistically significant.

Table 4

Excess valuxion multiples by recessions and non-recessionary periods.

\begin{tabular}{|c|c|c|c|}
\hline All & Non recession & Recession & $\mathrm{R}-\mathrm{NR}$ \\
\hline $\begin{array}{l}\text { Panel A: aver } \\
-0.46 \\
(-0.61)^{* 0 *} \\
{[303]}\end{array}$ & $\begin{array}{l}\text { four exces muls } \\
-0.44^{60 *} \\
(-0.59)^{-0 *} \\
{[266]}\end{array}$ & $\begin{array}{l}-0.65^{*-1 *} \\
(-0.76)^{*+*} \\
{[37]}\end{array}$ & $\begin{array}{l}-309^{*+*} \\
(-246)^{*+4}\end{array}$ \\
\hline $\begin{array}{l}\text { Panel B: exces } \\
-0.49^{*+*} \\
(-0.68) \\
{[279]}\end{array}$ & $\begin{array}{l}\text { huchales } \\
-0.46 \\
(-0.65)^{*+*} \\
{[245]}\end{array}$ & $\begin{array}{l}-0.67^{* *} \\
(-0.84)^{* *+} \\
{[34]}\end{array}$ & $\begin{array}{l}-289^{*+*} \\
(-217)^{* 4}\end{array}$ \\
\hline $\begin{array}{l}\text { Planel C: oxas } \\
-0.40^{*+*} \\
(-0.58) \\
{[87]}\end{array}$ & 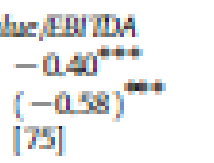 & $\begin{array}{l}-0.40^{*+} \\
(-047) \\
{[12]}\end{array}$ & $\begin{array}{l}a a_{3} \\
\left(\alpha_{25}\right)\end{array}$ \\
\hline $\begin{array}{l}\text { Panel D: axces } \\
-0.4 g^{*+*} \\
(-0.60)^{-0+} \\
{[102]}\end{array}$ & $\begin{array}{l}P S \\
-0.46 *+ \\
(-0.59)^{*+*} \\
{[90]}\end{array}$ & $\begin{array}{l}-0.64^{* *} \\
(-0.66)^{*+*} \\
{[12]}\end{array}$ & $\begin{array}{l}-211^{* 4} \\
(-1.14)\end{array}$ \\
\hline $\begin{array}{l}\text { Penel E: exce } \\
-0.35 \\
(-0.50) \\
{[10]}\end{array}$ & $\begin{array}{l}\text { ook velue equity } \\
-0.36 \\
(-0.51) \\
{[9]}\end{array}$ & $\begin{array}{l}-0.19 \\
(-0.19) \\
{[1]}\end{array}$ & $(0.35)$ \\
\hline
\end{tabular}

Not: We report the mean, median (in parentheses), and the number of observabors (in bradoets) for ench categary. The test stabisics (lastcolumn) are based on two-sumple

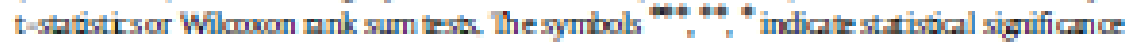
at 1\%, 5\%, and $10 \mathrm{rr}$ lavek, respectividy. 
Overall, the results show that recessions have an impact on valuation of takeover targets. During recessions valuation multiples are lower for both publicly traded targets and private targets. The discount of private targets relative to their public counterparts deepens during recessionary periods. These results suggest that recessions have an important impact on the corporate control market in the gaming industry. Given the numbers of privately held gaming companies that were acquired over our sample period during recessionary periods, these results have specific and significant importance to owners and investors of gaming companies. The deepened discount these privately held firms face should motivate concerns over the viability of this financial strategy for gaming companies during recessions.

\section{Context of the Study}

To place the study in context we briefly review the literature on mergers and acquisitions in the industry. One strand of the literature focuses on the merger success. Regardless of the definition of merger success, the realization of the synergy through successful integration is essential to create value. Thus, this line of literature pays a significant attention to discussing synergies (Canina, Kim, \& Ma, 2010). From an operational perspective, merger success is defined by operational performance that is improved compared to that before the merger.

However, from the perspective of the shareholders of the acquiring firm if the price paid for such improvement is too high, then the merger is not creating value for them regardless of operational gains. The shareholders of the target firm capture a larger share of gains from a takeover when the price paid is higher. The price paid in a takeover is critical for understanding the distribution of synergistic gains between the owners of the acquirer and the target.

The second strand of the literature studies who gains from mergers and acquisitions and how do owners of the acquiring and target firms split the gains from expected synergies. The overall evidence indicates lack of success, on average, for shareholders of the acquiring firm, even though it appears that M\&As do create value on average in the lodging industry (Canina et al., 2010). The critical component for understanding the division of gains from a merger is the price paid in an acquisition. Our paper contributes by studying valuations of transactions, specifically within the gaming industry.

Another strand of the literature that our study is related to is the literature on acquisitions of private versus public firms. This literature finds that, on average, across all industries, private target firms are acquired at a substantial discount relative to equivalent public firms. This may be explained by the relative liquidity between the private companies and the publicly traded firms (Officer, 2007). For 
example, (Ma, Zhang, \& Chowdhury, 2011) examine the listed and unlisted acquisitions in the lodging industry and find that acquirers in unlisted lodging deals earn significant positive abnormal returns, which increase with the relative deal size and the use of stock.

This study contributes on two dimensions to the understanding of relative valuation of public versus private targets in the gaming industry acquisitions. First, managers in a given industry (such as the gaming industry) are not concerned with the average effects for all industries, but rather with the effects within the industry where they operate. Thus, it is important to provide specific evidence in an industry-focused study, such as provided in this paper. Second, we investigate how private firm discount is related to economic conditions. We establish variation in private company valuation discount related to variation in economic conditions. Finally, there is some evidence that private acquirers may pay different premiums than publicly traded acquirers. Acquirers that operate publicly traded firms may have different costs of capital and thus may be able to raise capital at a different cost. It also may be the case that public acquirers - generally larger companies than private acquirers - perform more acquisitions and have a significant amount of acquisition experience. Consequently, these firms may be better at valuing, estimating, and realizing synergies. To control for these effects we study valuation multiples paid by public and private acquirers.

\section{Conclusion}

The study examines mergers and acquisition activity in the gaming industry in a comprehensive data set covering thirty years of transactions. The long time series allows us to capture both the times of economic expansions and recessions. An interesting and active market exists for corporate control in the gaming industry.

The study includes several new results. The first set of results speaks to the relative valuation of privately held takeover targets and public targets. There is evidence that privately held takeover targets in the gaming industry command lower valuations in takeovers than publicly traded firms. Various valuation ratios, such as Deal Value to Sales, Price to EPS, and Deal Value to EBITDA are lower for privately held targets than public targets. On average, the valuation multiples are $46 \%$ lower for private acquisition targets relative to public firms. This result has specific significance in the gaming industry since there were a large number of privately held gaming companies targeted for acquisition over our sample period. Owners and investors in this sector should be aware of the significant valuation discount they are likely to absorb if they monetize their holdings through an acquisition. 
The second set of results relates to the effect of the business cycle - recessions and expansions - on valuation. It has been established that the discount of private targets relative to public targets is present at all stages of the business cycle, both in expansions and in recessions. In addition, private targets receive relatively lower valuations in recessions: multiples paid for private targets during recessions relatively to public targets, are lower than during non-recessionary periods. Thus, the discount for private targets is deepened in recessions. Jointly, these results suggest that recessions have an important impact on the market for corporate control within the gaming sector.

These results bear implications for sellers of private firms and are consistent with a private firm discount. Sellers of private gaming firms should strive to find mechanisms to enhance their visibility and convey the value of their assets. Sellers of private firms, which might have weaker negotiation skills or at least lower acquisition experience than their public acquirers, should be careful when they negotiate the purchasing price. The results also indicate that these implications are even more relevant during recessions.

\section{References}

Braunlich, C. (1996). Lessons from the Atlantic City casino experience. Journal of Travel Research, 34, 46-56.

Canina, L. (1996). Initial public offerings in the hospitality industry - Underpricing and overperformance. Cornell Hotel and Restaurant Administration Quarterly, 37, 18-25.

Canina, L., Kim, J. Y., \& Ma, Q. (2010). What we know about M\&A success: A research agenda for the lodging industry. Cornell Hospitality Quarterly, 51(1), 81-101.

Chang, S. (1998). Takeovers of privately held targets, methods of payment, and bidder returns. Journal of Finance, 53(2), 773-784.

Chhabra, D. (2007). Estimating benefits and costs of casino gambling in lowa, United States. Journal of Travel Research, 46, 173-182.

Collins, J., Holcomb, T. R., Certo, S. T., Hitt, M. A., \& Lester, R. H. (2009). Learning by doing: Cross-border mergers and acquisitions. Journal of Business Research, 62, 1329-1334.

Goddard, J., Tavakoli, M., \& Wilson, J. (2009). Sources of variation in firm profitability and growth. Journal of Business Research, 62, 495-508.

Goyenko, R., Subrahmanyam, A., \& Ukhov, A. (2011). The term structure of bond market liquidity and its implications for expected bond returns. Journal of Financial and Quantitative Analysis, 46, 111139. 
Goyenko, R., \& Ukhov, A. (2009). Stock and bond market liquidity: A long-run empirical analysis. Journal of Financial and Quantitative Analysis, 44, 189-212.

Hayward, M., \& Hambrick, D. (1997). Explaining the premiums paid for large acquisitions: Evidence of CEO Hubris. Administrative Science Quarterly, 42, 103-127.

Hong, S. K., \& Hochan, J. (2005). Factors influencing purchasing time of a new casino product and its managerial implications: An exploratory study. Journal of Travel Research, 43, 395-403.

Huyghebaert, N., \& Luypaert, M. (2010). Antecedents of growth through mergers and acquisitions: Empirical results from Belgium. Journal of Business Research, 63, 392-403.

Jang, S. C., \& Young, N. (2009). Perceived quality, emotions, and behavioral intentions: Application of an extended Mehrabian-Russell model to restaurants. Journal of Business Research, 62, 451-460.

Kaplan, S., \& Ruback, R. (1995). The valuation of cash flow forecasts: An empirical analysis. Journal of Finance, 50, 1059-1093.

Kobeissi, N., Xian, S., \& Haizhi, W. (2010). Managerial labor-market discipline and the characteristics of merger and acquisition transactions. Journal of Business Research, 63, 721-728.

Kruse, T. (2002). Asset liquidity and the determinants of asset sales by poorly performing firms. Financial Management, 31, 107-129.

Kwan, A., \& McCartney, G. (2005). Mapping resident perceptions of gaming impact. Journal of Travel Research, 44, 177-187.

Lee, C. F., \& We, Y. L. (2009). Two-stage models for the analysis of information content of equity-selling mechanisms choices. Journal of Business Research, 62, 123-133.

Lees, S. (2003). Global acquisitions strategic integration and the human factor. New York: Palgrave Macmillan.

Ma, Q., \& Ukhov, A. (2011). Valuation of takeover targets and the market for corporate control throughout the business cycle. Insurance Markets and Companies: Analyses and Actuarial Computations, 2(1), 5-15.

Ma, Q., Whidbee, D., \& Zhang, A. (2012). Heterogeneous market responses and the listing effect in M\&A. Quarterly Journal of Finance, 2(02).

Ma, Q., Zhang, A., \& Chowdhury, N. (2011). Stock performance of acquiring listed and unlisted lodging assets. Cornell Hospitality Quarterly, 52(3), 291-301.

Makadok, R., \& Barney, J. B. (2001). Strategic factor market intelligence: An application of information economics to strategy formulation and competitor intelligence. Management Science, 47(12), 1621-1638. 
Morck, R., Shleifer, A., \& Vishny, R. (1990). Do managerial objectives drive bad acquisitions. The Journal of Finance, 45(1), 31-48.

Moss, S., Ryan, C., \& Wagoner, C. (2003). An empirical test of butler's resort product life cycle: Forecasting casino winnings. Journal of Travel Research, 41, 393-399.

Mowen, J. C., Fang, X., \& Scott, K. (2009). A hierarchical model approach for identifying the trait antecedents of general gambling propensity and of four gambling-related genres. Journal of Business Research, 62(12), 1262-1268.

Officer, Micah S. (2007). The price of corporate liquidity: Acquisition discounts for unlisted targets. Journal of Financial Economics, 83, 571-598.

Pablo, E. (2009). Determinants of cross-border M\&As in Latin America. Journal of Business Research, 62, 861-867.

Reuer, J., \& Ragozzino, R. (2007). Adverse selection and M\&A design: The roles of alliances and IPOs. Journal of Economic Behavior and Organization, 66(2), 195-212.

Shleifer, A., \& Vishny, R. (1992). Liquidation values and debt capacity. Journal of Finance, 47, 1343-1366.

Smeral, E. (1998). Economic aspects of casino gaming in Austria. Journal of Travel Research, 36, 33-39.

Smeral, E. (2009). The impact of the financial and economic crisis on European tourism. Journal of Travel Research, 48(1), 3-13.

Smith, S. (2006). How big, how many? Enterprise size distributions in tourism and other industries. Journal of Travel Research, 45, 53-58.

Soane, E., Dewberry, C., \& Narendran, S. (2010). The role of perceived costs and perceived benefits in the relationship between personality and risk-related choices. Journal of Risk Research, 13(3), 303-318.

Thaler, R. H., \& Johnson, E. J. (1990). Gambling with the house money and trying to break even: The effects of prior outcomes on risky choice. Management Science, 36(6), 643-660.

Vong, F. (2008). Changes in residents' gambling attitudes and perceived impacts at the fifth anniversary of Macao's gaming deregulation. Journal of Travel Research, 47(3), 388-397. 